\title{
Issues and Strategies of Translation Teaching for Economic Exteriorization in Urban Agglomeration of Harbin and Changchun
}

\author{
Lingyun Chu \\ Department of Foreign Languages \\ Harbin University of Commerce \\ Harbin, China
}

\begin{abstract}
Translation teaching and learning is the main prop of the development of regional economy and backs up the building of urban agglomeration of Harbin and Changchun which puts forward higher requirements for translation teaching of higher institutes. The paper aims to contribute to the exteriorization of economy in urban agglomeration of Harbin and Changchun through the investigation of the current situations of translation teaching in higher institutes and issues of its service for the development of regional economy.
\end{abstract}

Keywords-translation teaching; urban agglomeration of Harbin and Changchun; exteriorization

\section{INTRODUCTION}

In the 21st century, cross-cultural information and knowledge have been exerting important roles. Translation is the way to bridge the gap between different cultures and helps to build up the harmonious atmosphere around the globe. The Urban Agglomeration of Harbin and Changchun , one of the most important regional economic projects in China, depends on translation to exteriorize the economy and help related firms and corporations to open the foreign markets. They have interactive effects on each other and cannot be separated. Therefore it is necessary to study the links between translation teaching in higher institutes of Harbin and Changchun and, economic exteriorization which will give rise to the development of. The Urban Agglomeration of Harbin and Changchun

\section{EXTERIORIZATION OF ECONOMY IN URBAN AGGLOMERATION OF HARBIN AND CHANGCHUN}

In February of 2016, The State Council of China approved the "Planning for Urban Agglomeration of Harbin and Changchun" and pointed out that the "Planning" should implement the thoughts in the Third, Fourth and Fifth Plenary Sessions of the 18th Central Committee of the Communist Party of China (Houyuan Xing, 2014). The Council also stated that the provinces of Jilin and Heilongjiang should cooperate with each other and make specific plans and projects to turn the urban areas into influential, competitive, livable and pro-business urban

Projects: Education Science Planning Project in Heilongjiang Province (Youth Special Project) "On the Teaching Modes of Business English Translation from the Perspective of Translation Ecology" (GJD1215018); Heilongjiang Province Philosophy and Social Sciences Annual Planning Project "Heilongjiang Business English Talent Cultivation Ecological Model" (15EDB01). municipal groups, by taking the opportunity of One Belt and One Road and Northeast Area Revitalization Plan.

As with the urban agglomerations of Pearl River Delta, Yangtze River Delta and Beijing-Tianjin-Hebei, the HarbinChangchun Urban Agglomeration, as the only transprovincial municipal circle in the north- eastern part of China, aims to build up two economic zones with Harbin and Changchun as the cores. Covering the main cities in the middle of Jilin Province and the south-west of Heilongjiang Province, the Harbin and Changchun Agglomeration lies in the central area of North East Asia, which is the joint of China, Japan, South Korean, North Korean, Russia and Mongolia. It also serves as the significant tunnel that links North East Asia, Middle Asia and Europe which gives it priority to be the primary front line of opening-up in northeastern part of China. In light of the crucial strategic position, Urban Agglomeration of Harbin and Changchun is to integrate itself into the China's national strategy of One Belt and One Road and take active part in international division of labour to accelerate the exteriorization of regional economy and improve the comprehensive national strength.

\section{ANALYSIS OF THE CURRENT SITUATIONS OF \\ TRANSLATION TEACHING OF HIGHER EDUCATION FOR REGIONAL ECONOMY}

There are totally 48 universities and colleges in Harbin, 15 adult universities, 20 postgraduate education institutes. The number of graduates of translation annually has reached beyond 10,000. With the expansion of cities and development of Harbin and Changchun Agglomeration, there will definitely be a dire need of translation talents with higher level of expertise. Therefore, it is urgent to find a solution to the problem, that is, how to foster more skillful translation intellects to serve for the exteriorization of economy in Harbin and Changchun Agglomeration.

\section{A. Issues on Translation Teaching of Higher Institutes in Harbin for Economic Exteriorization}

In the first place, the translation talents have not met the requirements of exteriorization of economy in Harbin. The exteriorization of economy is a complicated social project 
which demands the close cooperation of intellects of different fields and the dynamic balance between different levels of intellects in accordance with the changes of social needs. Therefore, productivity is the decisive factor in the system of talents cultivation. In recent years, responding promptly to the Party's principle of Rebounding Northeast Old Industry Base, the Harbin municipal government attaches great importance to the revitalization of industry. As a result, the optimization of industrial structure, industrialization and mechanization in Harbin have been growing fast and the Hi-tech industry is undergoing dramatic promotion. This requires high qualified translation talents with inter-disciplinary background. The major concerns in translation teaching in higher education institutes are the number of post-graduates and the scale of post-graduate education. The number of post-graduates of the translation major is far from enough and much less than that of graduates although it has continued to grow these years. What's worse, instead of staying in Harbin, the graduates and post-graduates of higher education institutes in Harbin tend to land jobs in the southern part of China. The ultimate reason why the university and college students are less attracted to Harbin is that the regional economy of Harbin falls far behind that of the coastal cities in the south.

In the second place, the qualities of teaching staff fail to satisfy the requirements of exteriorization of economy in Harbin and Changchun Agglomeration. With the opening-up policy, firms and companies overseas are eager to recruit compound talents with specialty, capability and knowledge in order to fulfill the enterprises' needs to deal with events in such fields as foreign trade, laws concerning foreign affairs, outsourcing services. However, most of the teachers major in literature, linguistics, translation and few of them specialize in economics, politics, finance, or other areas. Take Harbin University of Commerce for example. There are totally 30 teachers in English Major, Business English Major and Russian Major among which only one teacher has the background of Management and Two teachers' specialization is Business English. Except them, all the teachers take interest in studying and analyzing theories and practices related to literature, linguistics and translation. Such allocation of teachers cannot meet the new challenges posed by the exteriorization of economy in Harbin and Changchun Agglomeration which will impede the personnel cultivation or even the exteriorization of economy in Urban Agglomeration of Harbin and Changchun.

Finally, the backwardness of foreign language instruction resources, to some extent, has exerted influence on building up exteriorization of economy in Urban Agglomeration of Harbin and Changchun. Foreign language instruction resources include multimedia classrooms, standardized classrooms for translation teaching (holding capacity of 25 students), audio-visual classroom and library. In China, the allocation of foreign language instruction resources varies according to different parts of the country. The coastal cities in the south east enjoys most of the foreign language instruction resources with all kinds of classrooms, advanced equipment, which sees to it that the modern teaching concepts and approaches will be implemented in the teaching process. Hence, in the northeast where the regional economy is underdeveloped, it is difficult to build audio-visual classrooms let alone other kinds of classrooms, which handicaps the application of the latest teaching approach and the newly-developed theoretical ideas of second language acquisition. The traditional teaching approach discourages students' interest in learning second foreign language, which causes the low quality of teaching. The negative circle of foreign language acquisition poses difficulties to the training of high qualified graduates and post-graduates of translation and eventually has bad impact on the exteriorization of economy.

\section{B. Reasons for Issues on Translation Teaching of Higher Institutes in Harbin for Exteriorization of Economy}

The reasons for issues on translation teaching of higher institutes in Harbin for the exteriorization of economy in Urban Agglomeration of Harbin and Changchun go as follows:

Firstly, the ways and means of training translation talents are inappropriate and inefficient, which accounts for the possibility of not fulfilling the needs and demands of exteriorization of economy in Urban Agglomeration of Harbin and Changchun. The inappropriateness and inefficiency of higher education of translation teaching is mainly because of the imbalanced hierarchical structure of translation teaching in higher educational institutes. In this hierarchy of colleges and universities in Harbin, graduates with Bachelor's degrees take up the greatest proportion of graduates of higher educational institutes, followed by students graduating from Vocational and Technical Colleges and the students graduating from Vocational and Technical Colleges postgraduates occupies the smallest proportion among all levels of graduates. In accordance with data collected, there were totally 30,000 full-time students in colleges and universities in Harbin, of which postgraduates took up $15 \%$ with students in Vocational and Technical Colleges postgraduates occupying nearly $20 \%$, and the graduates account for $65 \%$. It is agreed that the sound hierarchical structure of talents should be in the shape of pyramid or ladder. However, the hierarchy of talents in Harbin is diamond-shaped with. Therefore it is safe to conclude that the hierarchy of talents in Harbin is unsound which brings about the mismatch between the hierarchical structure of talents training system and social needs.

Secondly, the regional economy in Harbin and Changchun has been underdeveloped. The regional economic development is the support of translation teaching and learning or even higher education. The economic development of regions and areas will provide the translation teaching and higher education with materials and the levels of regional economic development will decide the investment of education. Generally speaking, China's GDP has always been increasing. But in the light of geographical, historical and resourceful factors, there is no consistency between the levels of economic development in different regions. The coastal cities in the south eastern part of China ranked as the top in economy, boast of their fast economic growth and dynamism. Next to the coastal cities, the areas 
and regions in the middle of the country enjoy fast development. The north eastern and western parts lag behind in the development of economy. Located in old industrial base, the cities of Harbin and Changchun advanced slowly in view of the inconvenient transportation, and meanwhile it also exerts negative influence on the growth of regional economy and the exteriorization. As one of the underdeveloped regions in China, the municipal government will only allocate limited amount of financial support to higher education let alone translation training in foreign language education and training.

Apart from the financial allocation of the local government, the investment of firms and corporations is another important source of funding. The purpose of business investment is to increase interests or benefits. But it is unlikely to turn the results of liberal studies into productivity and therefore it is impossible for the liberal researchers to seek business investment.

\section{STRATEGIES FOR REFORMS IN FOREIGN TEACHING OF HIGHER EDUCATION}

It is certain that translation teaching and learning of higher education plays important roles in exteriorization of economy. However, according to the said analyses, numerous questions have arisen in the process of the exteriorization of Urban Agglomeration of Harbin and Changchun. In order to accelerate the development of Urban Agglomeration of Harbin and Changchun and render services to exteriorization of economy, the reforms of translation teaching can be done from the following two aspects.

\section{A. Strategies for Interior Reforms of Translation Teaching in Colleges and Universities}

First of all, the educational notions and ideas should be renewed. Upholding the educational philosophy of fostering talents in a scientific and objective way, we should build up the talents-foresting-oriented educational system of translation teaching and learning and evoke heated discussions about the innovation of educational notions and ideas. We should also learn from the experiences of translation teaching and learning in the past decades, by using empirical experiences of western countries for reference, keep pace with the international development of translation teaching and learning and form the new principles of ideology of translation teaching with Chinese characteristics. Due to the continuous explorations and constant breakthrough in the past decades, scholars and experts in translation teaching and learning are able to deepen their understanding of compound translation talents and translation talents with practical skills, which helps the establishment of the disciplines of Translation and Business English.

However, it is rather essential to further probe into such propositions as "translation teaching and learning as humanistic education", "translation teaching and learning as subject education", " integration of language and content teaching" (or content-based teaching), "cultivation of critical thinking ability", "development of cross-cultural awareness" and "regional and national research personnel training" so as to promote the innovation and development of professional transaltion personnel training modes.

Additionally, it is necessary to conduct studies of projects on the exteriorization of economy in Urban Agglomeration of Harbin and Changchun and translation teaching and learning. Through the studies of these projects, National Steering Committee on Translation teaching and Learning will effectively and efficiently serve as "Think Tank" in the reforms of translation teaching and learning. The exteriorization of economy in Urban Agglomeration of Harbin and Changchun is also in need of such a "Think Tank", under the guidance of which, we can research on some major issues and concerns in the reforms of education in response to the demands of the exteriorization of economy in Urban Agglomeration of Harbin and Changchun. We should establish fair, impartial and open project approval systems and call for projects every year to select the best among them in order to assist the reforms in translation teaching and learning with intellects and talents and to contribute to the development of the exteriorization of economy in Urban Agglomeration of Harbin and Changchun.

Finally, the level of teaching staff should be improved. Based on big data from field investigations, Dai Weidong (2014) found that the problems with translation teachers are as follows: the serious shortage of translation teachers, the gap between the actual level of teachers and the social requirement for teachers, the out-of-date teaching concepts and ideas and the out-dated teaching methods and obsolete equipment. In order to solve these problems, the related organizations and units make every effort to build development and exchange platform for transaltion teachers, especially young teachers to improve the teachers' professionalism and better the teaching methods.

\section{B. Strategies for Exterior Reforms of Translation Teaching in Colleges and Universities}

Firstly, the government should provide support for the reforms of translation teaching and learning of higher education. The government shall bridge the cooperation between higher education institutes and the enterprises by creating a harmonious business atmosphere. Meanwhile the government should respond immediately to the problems and issues in the reform of translation teaching and learning to see to it that the reform will be conducted smoothly. Moreover, the government shall expand investment into the reforms of translation teaching and learning and increase financial support for research and technology. Special funds should be set up to encourage scholars and experts in higher education institutes to initiate projects on the link between the exteriorization of economy in Urban Agglomeration of Harbin and Changchun and translation teaching and learning

Apart from this, the society should well build outside conditions in order to help the higher institutes to obtain the support for the reform of translation teaching and learning. Through the collaborations between the colleges and universities and enterprises, the higher educational institutes 
will be able to enjoy good reputation in firms and corporations. The government should also publicize higher educational institutes and invite the companies and individual dealers to take part in the reforms of translation teaching and learning and boost the smooth running of the reform.

\section{CONCLUSION}

The exteriorization of economy in Urban Agglomeration of Harbin and Changchun is a systematic project in which translation plays an important and significant role. The translation personnel training depends on the leading edge of training system and educational principles. Thus the reforms of translation teaching and learning are imperative and necessary. Through the investigation of issues on the exteriorization of economy in Urban Agglomeration of Harbin and Changchun and analysis of the corresponding reasons, the paper proposes strategies from the interior and exteriors aspects in the hope that it will contribute to the development of the exteriorization of economy in Urban Agglomeration of Harbin and Changchun and narrow the gap between the exteriorization of economy in Urban Agglomeration of Harbin and Changchun and translation teaching and learning of higher education. Additionally, the principles and strategies proposed in the paper will guide the translation teaching in colleges and universities.

\section{REFERENCES}

[1] Houyuan Xing. Current Situations of Chinese Enterprises and Requirements for Language Services. [J].Chinese Translators Journal,2014.

[2] Lingyun Chu. Research on Ecological Modes of Business English Teaching. [J].Teaching of Forestry Region,2016.

[3] Nataly Kelly, Robert G. Stewart. The Language Services Market: 2011 An Annual Review of the Translation, Localization, and Interpreting Services Industry. Common Sense Advisory, Inc., 2011.

[4] Rebecca Ray, Nataly Kelly, Robert G. Stewart. Translation Performance Metrics, Common Sense Advisory, Inc., 2011.

[5] Weidong Dai. Thoughts on the construction of foreign language majors in the context of the translation teaching in China.[J].Foreign Language World,2014. 